\title{
ANALISA ASPEK-ASPEK DALAM PROSEDUR CHANGE ORDER PADA PROYEK KONSTRUKSI
}

Michael Halmar Kosasi,. ${ }^{1}$, Andi ${ }^{2}$, Lie Arijanto ${ }^{3}$

\begin{abstract}
ABSTRAK : Change order merupakan perubahan kondisi kontrak yang mengubah harga, dan schedule proyek. Penelitian sebelumnya menunjukan claim change order mencapai $50 \%$ dari keseluruhan claim, dimana $76 \%$ diantaranya merupakan change order lisan dan separuhnya mengalami kegagalan claim. Tujuan penelitian adalah mengetahui berbagai aspek dalam prosedur change order. Metode penelitian yaitu dengan membuat kuesioner berdasarkan literatur terhadap "frekuensi kejadian" dan "tingkat kepentingan". Data dianalisa deskriptif untuk mendalami kondisi proyek dan literatur beserta penyebabnya secara mendalam, yang kemudian dilakukan analisa perbedaan kontraktor dan MK melalui uji T-Test. Berdasarkan analisa diketahui saat identifikasi, change order diprakarsai owner, kontraktor, MK dengan site instruction, selanjutnya kontraktor harus mengajukan proposal gambar, spesifikasi, harga, dokumentasi. Selanjutnya owner akan mengevaluasi harga satuan dan mengukur volume bersih berdasar perubahan gambar. Pada tahapan approval, owner memberikan tanda tangan berdasarkan harga yang disetujui. Payment dilakukan dengan invoice terpisah sesuai progress change order beserta biaya tidak langsung, sedangkan tambahan waktu diberikan dalam hari kalender.
\end{abstract}

Kata kunci: change order, aspek dalam prosedur, frekuensi kejadian, tingkat kesetujuan

ABSTRACT : Change orders are changes in contract conditions change prices, and the project schedule. Previous research shows change order claims reaches $50 \%$ of total claim, where $76 \%$ given in verbal, and half have failed. The research objective is to determine the various aspects of the change order procedure. The research method is to create a questionnaire based on the literature of the "frequency of occurrence" and "level of interest". Data were analyzed descriptively to explore the conditions of the project and literature and how it happens, analyzed the differences contractors and MK through T-Test. Based on the analysis found that identification phase, change orders initiated by the owner, the contractor, MK with site instruction, then the contractor must submit a proposal drawings, specifications, price, documentation. Next phase, owner will evaluate the unit price and measuring the net volume based on changes drawing. At approval phase, owner provides a signature based on the agreed price. Payment is done by a separate invoice based on progress including indirect costs, while additional time is given in calendar days.

Keywords : change order, aspects of the procedure, frequency of occurrence, level of interest

\section{PENDAHULUAN}

Pekerjaan tambah kurang merupakan hal yang sangat lazim terjadi pada proyek konstruksi, penyebabnya berbagai macam hal dan dapat disebabkan oleh berbagai pihak seperti Owner, Konsultan, Kontraktor ataupun kondisi lainnya (Keane, Sertyeselisik\& Ross, 2010). Karena menyangkut berbagai pihak maka change order harus dilakukan dengan prosedur yang tepat dan telah disepakati bersama. Prosedur change order dapat berbeda antara satu proyek dengan proyek lainnya sehingga pada penelitian ini akan digunakan suatu literatur sebagai dasar prosedur change order. Pada proyek konstruksi pekerjaan tambah kurang disebut pula sebagai change order atau variation yang merupakan perubahan suatu kondisi dari dokumen kontrak awal yang dibuat secara tertulis dan terdokumen antara pemilik proyek dengan pelaksana proyek yang dapat mengubah biaya kontrak, jadwal proyek dan jadwal pembayaran kontrak (Swantari, 2013).

\footnotetext{
${ }^{1}$ Mahasiswa Program Studi Magister Teknik Sipil Universitas Kristen Petra, m01515004@john.petra.ac.id

2Dosen Program Studi Magister Teknik Sipil Universitas Kristen Petra, andi@peter.petra.ac.id

${ }^{3}$ Dosen Program Studi Magister Teknik Sipil Universitas Kristen Petra, arijanto_lie@yahoo.com
} 
Salah satu contoh pada penelitian sebelumnya jika prosedur change order tidak dilakukan dengan tepat adalah lebih dari 50\% dari sample proyek penelitian pada tahun 2001 tidak dapat melakukan change order claim dikarenakan tidak adanya dokumentasi yang tepat (EINemr, 2001). Penelitian yang akan dilakukan adalah dengan melakukan pengumpulan data frekuensi kejadian dan tingkat kepentingan aspek dalam prosedur change order yang dilakukan terhadap tahapan identifikasi penerbitan change order, evaluasi pengajuan penerbitan change order, approval penerbitan change order, dan payment change order. Data yang dikumpulkan kemudian dianalisa secara mendalam sehingga dapat diketahui kontekstual prosedur change order yang terjadi pada proyek konstruksi.

\section{TINJAUAN PUSTAKA}

\subsection{Definisi Change Order}

Change order adalah mengubah suatu kondisi dari dokumen kontrak awal yang dibuat secara tertulis dan terdokumen antara pemilik proyek dan pelaksana proyek seperti menambah dan mengurangi pekerjaan ataupun perubahan yang dapat mengubah spesifikasi biaya kontrak, jadwal proyek dan jadwal pembayaran (Swantari,2013).

\subsection{Jenis Change Order}

Berdasarkan ada tidaknya dokumen change order, maka secara mendasar change orderdapat dibedakan menjadi 2 jenis, yaitu: (Gilbreath, 1992)

1. Formal Changes (Directed Changes) dibuat oleh owner dalam bentuk tertulis yang ditujukan secara langsung kepada kontraktor untuk mengubah cakupan pekerjaan, waktu pelaksanaan, harga dan segala sesuatu yang telah dibuat dalam kontrak (Gilbreath, 1992).

2. Informal Changes (Constructive Changes) adalah tindakan informal berupa tindakan melakukan modifikasi pada kontrak yang disebabkan oleh kelalaian dan disadari harus dilakukan suatu perubahan, serta beberapa tindakan yang dapat menyebabkan pembengkakan biaya dan waktu dari kontraktor. (Fisk, 2006).

\subsection{Prosedur Change Order}

\subsubsection{Prosedur Menurut Literatur Fisk (2006)}

Secara umum alur change order terbagi menjadi 2 tahap, yaitu:

1. Initiation of Change Orders

2. Change Order Preparation

Pada tahap initiation of change order umumnya change order diajukan oleh personil konstruksi yang berada di lapangan, akan tetapi selain personil tersebut pengajuan change order juga dapat dilakukan oleh berbagai pihak seperti kontraktor, konsultan desain, pihak ketiga, serta seluruh pihak yang ada dapat mengajukan change order akan tetapi yang memiliki otoritas untuk memberikan izin adalah owner. Pada tahap change order preparation Dokumen yang mengubah point pada kontrak bagaimanapun harus dipertimbangkan sebagai change order. Dokumen harus ditandatangani oleh owner atau oleh seseorang yang memiliki kekuatan untuk mewakilinya. architect or engineer's field order hanya menyediakan tanda tangan arsitek atau engineer sehingga tidak memenuhi kebutuhan akan terjadinya change order kecuali jika tanda tangan arsitek atau engineer tersebut memiliki kemampuan untuk memberikan ijin.

\subsubsection{Prosedur Menurut Literatur Gilbreath (1992)}

Tahapan change order secara umum terbagi menjadi 5 tahap, yaitu:

1. Identification

2. Evaluation

3. Approval

4. Incorporation

5. Payment 
Pada tahap identification diidentifikasikan seberapa banyak perubahan yang terjadi, terutama yang bersifat informal, dan tidak dapat dikenali. Pada tahap evaluation pihak owner harus memutuskan apakah owner mau melakukan perubahan. Evaluasi dari pekerjaan change order yang diajukan mengandung review dari penawaran kontraktor untuk keakuratan, dan kesesuaian dengan kontrak. Pada tahap approval owner dapat menolak dan mengembalikan penawaran yang diberikan kontraktor dan meminta penawaran baru. Selanjutnya pada tahap Incorporation kontraktor diminta untuk mengubah dan memodifikasi persetujuan awal. Pada tahap approval dokumen change order harus diberi nomor dan tanggal, dan harus diberi tandatangan oleh pihak kontraktor yang menandakan setuju akan mengerjakan change order dengan kompensasi yang telah disetujui. Terakhir pada tahap payment, pembayaran untuk pekerjaan change order harus mengikuti prosedur yang sama dengan yang telah dijelaskan pada pembayaran progress kontrak normal.

\subsubsection{Prosedur Menurut Literatur Hardjomuljadi (2006)}

Perubahan pekerjaan yang dimaksud adalah perubahan kontrak yang menjabarkan pekerjaan yang telah diisyaratkan untuk dikerjakan, sedangkan pekerjaan ekstra melibatkan tambahan item pekerjaan yang tidak termasuk pada kontrak awal, baik dalam bentuk perubahan ataupun tambahan yang melibatkan item pekerjaan yang tidak terdapat dalam kontrak asli adalah modifikasi dari kontrak asli. Apabila kontraktor tahu formalitas apa yang diperlukan kontraktor untuk memperoleh tambahan biaya dan penyesuaian waktu yang ditetapkan dalam FIDIC CC dan bagaimana menggunakan FIDIC CC untuk penyesuaian biaya dan waktu terhadap perubahan maka FIDIC CC memberikan fleksibilitas yang lebih besar, dan fleksibilitas ini diperoleh dengan mengizinkan perubahan tanpa perlu adanya kontrak baru untuk semua jenis penambahan, penghapusan dan perubahan pekerjaan.

\subsubsection{FIDIC Red Book (1999)}

Apabila enjinir meminta suatu usulan, sebelum memerintahkan suatu variasi, kontraktor harus menanggapi secara tertulis sesegera mungkin, dengan menyampaikan alasan mengapa kontraktor tidak dapat memenuhinya (apabila hal ini terjadi) atau dengan menyampaikan: Suatu uraian mengenai cara pelaksanaan pekerjaan yang diusulkan dan rencana pelaksanaannya,

- Usulan kontraktor untuk modifikasi terhadap program yang diperlukan sesuai dengan Sub-Klausula 8.3 [Rencana Kerja] dan terhadap Waktu Penyelesaian,

- Usulan kontraktor untuk evaluasi variasi.

\section{METODOLOGI PENELITIAN}

\subsection{Studi Literatur}

Penelitian ini dilakukan dengan diawali suatu pendahuluan yaitu mencari latar belakang alasan penelitian ini dilakukan agar dapat diketahui dengan lebih jelas bagaimana aspek aspek dalam prosedur change order yang terjadi dari berbagai responden yang telah bekerja di proyek konstruksi.

\subsection{Penentuan Sampel}

Populasi pada penelitian ini adalah stakeholder yang pernah bekerja sebagai kontraktor ataupun konsultan pengawas (MK) di wilayah Surabaya sehingga jawabannya berdasarkan pengalaman pribadi, sedangkan sampel adalah bagian dari populasi tersebut.

\subsection{Pembuatan Kuesioner}

Kuesioner dibuat bersifat tertutup (Closed-Ended Questions), sehingga jawaban responden telah disediakan pada pilihan jawaban. Pembuatan kuesioner didasarkan kepada literatur seperti dapat dilihat pada Tabel 1. 
Tabel 1. Kuesioner Identifikasi Penerbitan Change Order

\begin{tabular}{|c|c|c|}
\hline Literatur & No & Pernyataan Kuesioner \\
\hline \multirow{3}{*}{$\begin{array}{l}\text { Change order biasanya muncul dan } \\
\text { disebabkan oleh owner, engineer maupun } \\
\text { kontraktor, akan tetapi change order juga } \\
\text { dapat terjadi karena permintaan pihak lain } \\
\text { seperti desainer, ataupun agen publik, pihak } \\
\text { manapun yang berkepentingan pada proyek } \\
\text { dapat menyebabkan terjadinya change order." } \\
\text { (Fisk, 2006) }\end{array}$} & 1.1 & $\begin{array}{l}\text { Change order diprakarsai oleh } \\
\text { owner serta perwakilanya. }\end{array}$ \\
\hline & 1.2 & Change order diprakarsai oleh MK. \\
\hline & 1.3 & $\begin{array}{l}\text { Change order diprakarsai oleh } \\
\text { kontraktor. }\end{array}$ \\
\hline
\end{tabular}

\subsection{Uji Validitas dan Reliabilitas}

Pengujian validitas dilakukan dengan menghitung nilai Corrected Item-Total Correlation yang dihitung sebagai berikut:

rtt $=$ Corrected Item Total Correlation

$$
\mathrm{rtt}=\mathrm{n}(\hat{\mathrm{r}}) /(1+(\mathrm{n}+1)(\hat{\mathrm{r}})(1)
$$

$\hat{\mathrm{r}} \quad=$ Rata - rata intercorelation

$\mathrm{n} \quad=$ Jumlah indikator

Sedangkan reliabilitas menunjukan konsistensi dan stabilitas dari suatu skor atau skala pengukuran. Uji reliabilitas dilakukan dengan menghitung nilai Cronbach alpha, sebagai berikut:

$\mathrm{n} \quad=$ Jumlah sampel

$$
r=\frac{\mathrm{n} \sum X Y-\left(\sum X\right)\left(\sum Y\right)}{\sqrt{\left[n \sum X^{2}-\left(\sum X\right)^{2}\right]} \sqrt{\left[n \sum Y^{2}-\left(\sum Y\right)^{2}\right]}}
$$

$\mathrm{x} \quad=$ Skor indikator yang diuji

$\mathrm{y} \quad=$ Skor indikator lain

Apabila hasil perhitungan Cronbach alpha > 0,6 maka item yang digunakan pada penelitian di dalam kuesioner disebut reliabel.

\subsection{Analisa Frekuensi Kejadian dan Tingkat Kepentingan Prosedur Change Order pada Proyek Konstruksi}

Hasil pengumpulan data melalui kuesioner dengan skala "Frekuensi Kejadian" dan "Tingkat Kepentingan" maka data tersebut dirata - rata atau dihitung meannya. Metode analisa mean dihitung sebagai berikut:

$$
\begin{array}{ll}
\mathrm{Me} & =\text { Nilai rata }- \text { rata (mean) } \\
\mathrm{n} & =\text { Jumlah responden } \\
\mathrm{Xi} & =\text { Data ke-i } \\
\sum X i & =\text { Jumlah keseluruhan data }
\end{array}
$$

$$
\mathrm{Me}=\sum X i / \mathrm{n}(3)
$$

\subsection{Analisa Perbedaan Frekuensi Kejadian Kontraktor dan MK pada Prosedur Change Order}

Analisa perbedaan dilakukan dengan $T$ - Test sampel independent untuk mengetahui signifikansinya. Analisa T - Test sampel independent terhadap perbedaan "Frekuensi Kejadian" kontraktor dan MK dihitung dengan persamaan sebagai berikut:

$$
\mathrm{t}=((\mathrm{M} 1-\mathrm{M} 2)-\mathrm{Mh}) / \mathrm{SD}(4)
$$

$\mathrm{t}=\mathrm{r}-$ ratio $/ \mathrm{t}-$ test $/ \mathrm{t}$ analisis yang dihitung

M1 = rata - rata pada kelompok 1

M2 = rata - rata pada kelompok 2

Mh = Mean hipotetik

SD = Standar kesalahan mean 


\subsection{Analisa Perbedaan Tingkat Kepentingan Kontraktor dan MK pada Prosedur Change Order}

Analisa perbedaan dilakukan dengan $T$ - Test sampel independent untuk mengetahui signifikansinya. Analisa T - Test sampel independent terhadap perbedaan "Tingkat Kepentingan" kontraktor dan MK dihitung dengan persamaan (4).

\section{ANALISA DATA DAN PEMBAHASAN}

\subsection{Analisa Deskriptif Identifikasi Penerbitan Change Order}

Dapat dilihat pada Tabel 2. Untuk responden kontraktor dan MK nilai mean frekuensi kejadian change order diprakarsai oleh owner adalah 4.11 dan 4.32, diprakarsai oleh MK 3.57 dan 3.39, dan diprakarsai oleh kontraktor 3.27 dan 3.82. Sehingga change order sering diprakarsai oleh owner, MK, dan kontraktor. Selain itu pada Tabel 2. dapat dilihat pula nilai mean site instruction digunakan sebagai satu- satunya dokumen untuk penerbitan change order lebih tinggi dari site memo, yaitu $3.41>2.50$ untuk responden kontraktor dan $3.36>$ 2.57 untuk responden MK, sehingga bentuk perintah tertulis yang dapat digunakan adalah dalam bentuk site instruction. Site instruction tersebut dapat diterbitkan baik oleh owner dan MK dimana nilai mean frekuensi kejadian keduanya memiliki nilai lebih dari 3.5.

Tabel 2. Mean Identifikasi Penerbitan Change Order

\begin{tabular}{|c|c|c|c|c|c|}
\hline \multirow[t]{2}{*}{ No } & \multirow[t]{2}{*}{ Pernyataan Kuesioner } & \multicolumn{2}{|c|}{$\begin{array}{c}\text { Mean } \\
\text { Frekuensi } \\
\text { Kejadian }\end{array}$} & \multicolumn{2}{|c|}{$\begin{array}{c}\text { Mean } \\
\text { Tingkat } \\
\text { Kepentingan }\end{array}$} \\
\hline & & Kon. & MK & Kon. & MK \\
\hline 1.1 & Change order diprakarsai oleh owner serta perwakilanya & 4.11 & 4.32 & 3.68 & 3.39 \\
\hline 1.2 & Change order diprakarsai oleh MK & 3.57 & 3.39 & 3.48 & 3.32 \\
\hline 1.3 & Change order diprakarsai oleh kontraktor & 3.27 & 3.82 & 3.18 & 3.18 \\
\hline 1.13 & $\begin{array}{l}\text { Site memo digunakan sebagai satu - satunya dokumen untuk } \\
\text { penerbitan change order }\end{array}$ & 2.50 & 2.57 & 2.66 & 2.71 \\
\hline 1.15 & Site instruction diterbitkan owner & 3.82 & 3.71 & 3.77 & 3.32 \\
\hline 1.16 & Site instruction diterbitkan oleh MK & 3.84 & 3.61 & 3.89 & 3.57 \\
\hline 1.17 & $\begin{array}{l}\text { Site instruction digunakan sebagai satu - satunya dokumen untuk } \\
\text { penerbitan change order }\end{array}$ & 3.41 & 3.36 & 3.70 & 3.54 \\
\hline
\end{tabular}

\subsection{Analisa Deskriptif Evaluasi Pengajuan Penerbitan Change Order}

Berdasarkan nilai mean yang dapat dilihat apda Tabel 3. diketahui nilai mean frekuensi kejadian responden kontraktor dan MK, owner akan mengakui change order karena adanya perubahan merek material sebesar 3.75 dan 3.89, perubahan spesifikasi 4.16 dan 4.18, serta perubahan gambar 4.25 dan 4.32. Hal tersebut menunjukan terjadinya perubahan merek, spesifikasi, dan gambar merupakan hal - hal yang dapat diajukan sebagai change order dan akan disetujui oleh owner. Berdasarkan nilai mean tersebut dapat diketahui nilai mean terbesar adalah perubahan gambar, hal ini dibuktikan dari besarnya nilai tingkat kepentingan perubahan gambar lebih besar dari perubahan spesifikasi dan merek, yaitu hingga 4.46 yang berarti sangat penting. 
Tabel 3. Mean Evaluasi Pengajuan Penerbitan Change Order

\begin{tabular}{|c|l|c|c|c|c|}
\hline \multirow{2}{*}{ No } & \multicolumn{1}{|c|}{ Pernyataan Kuesioner } & \multicolumn{2}{|c|}{$\begin{array}{c}\text { Mean } \\
\text { Frekuensi } \\
\text { Kejadian }\end{array}$} & \multicolumn{2}{|c|}{$\begin{array}{l}\text { Mean } \\
\text { Tingkat } \\
\text { Kepentingan }\end{array}$} \\
\cline { 3 - 7 } 2.1 & $\begin{array}{l}\text { Owner mengakui perubahan merek material sebagai dasar } \\
\text { penerbitan change order }\end{array}$ & 3.75 & 3.89 & 4.02 & 3.96 \\
\hline 2.2 & $\begin{array}{l}\text { Owner mengakui perubahan spesifikasi sebagai dasar penerbitan } \\
\text { change order }\end{array}$ & 4.16 & 4.18 & 4.23 & 4.36 \\
\hline 2.3 & $\begin{array}{l}\text { Owner mengakui perubahan gambar sebagai dasar penerbitan } \\
\text { change order }\end{array}$ & 4.25 & 4.32 & 4.25 & 4.46 \\
\hline
\end{tabular}

\subsection{Analisa Deskriptif Approval Penerbitan Change Order}

Pada hasil penelitian yang dapat dilihat pada Tabel 4. Diketahui nilai mean change order yang dilaksanakan hanya dengan perintah lisan dari owner adalah 3.77 dan 3.86 untuk responden kontraktor dan MK, sedangkan untuk nilai mean change order yang dilaksanakan hanya dengan perintah lisan dari MK adalah 3.66 dan 3.64 untuk responden kontraktor dan MK. Hal ini menunjukan bahwa change order yang dilaksanakan tanpa perintah tertulis akan sering untuk tidak disetujui, oleh karenanya lebih baik site instruction diterbitkan terlebih dahulu. Selanjutnya untuk tingkat kepentingan MK menganggap bahwa change order yang tidak memiliki site instruction akan sangat penting untuk tidak disetujui karena prosedur yang tidak tepat dengan nilai mean lebih dari 4.

Tabel 4. Mean Evaluasi Approval Penerbitan Change Order

\begin{tabular}{|c|l|c|c|c|c|}
\hline \multirow{2}{*}{ No } & \multicolumn{1}{|c|}{ Pernyataan Kuesioner } & \multicolumn{2}{|c|}{$\begin{array}{c}\text { Mean } \\
\text { Frekuensi } \\
\text { Kejadian }\end{array}$} & \multicolumn{2}{|c|}{$\begin{array}{c}\text { Mean } \\
\text { Tingkat } \\
\text { Kepentingan }\end{array}$} \\
\cline { 3 - 6 } 3.3 & $\begin{array}{l}\text { Kon. } \\
\text { Change order yang telah dilaksanakan hanya dengan instruksi } \\
\text { lisan dari owner tidak disetujui }\end{array}$ & 3.77 & 3.86 & 3.48 & 4.18 \\
\hline 3.4 & $\begin{array}{l}\text { Change order yang telah dilaksanakan hanya dengan instruksi } \\
\text { lisan dari MK tidak disetujui }\end{array}$ & 3.66 & 3.64 & 3.64 & 4.07 \\
\hline
\end{tabular}

\subsection{Analisa Deskriptif Payment Change Order}

Pada tahap akhir pembayaran atau payment dapat dilihat pada Tabel 5. nilai mean untuk pembayaran change order harus menggunakan invoice terpisah dari tagihan normal sebesar 4.11 dan 4.50 untuk responden kontraktor dan MK, sehingga pembayaran yang dilakukan pada proyek menggunakan invoice yang terpisah. Untuk nilai mean pembayaran change order sesuai dengan progress dan pembayaran di akhir proyek memiliki nilai kisaran yang sama yaitu diantara 3.4 hingga 3.8 untuk kontraktor dan MK, sehingga kedua kondisi sama sama sering terjadi. Literatur menyebutkan bahwa pembayaran change order dilakukan sesuai dengan progress pekerjaan normal kecuali apabila hal tersebut telah disebutkan pada kontrak. Hal tersebut kemudian diperdalam dan diketahui melalui wawancara pelaku konstruksi bahwa pembayaran change order yang dilakukan di akhir proyek dilakukan agar pembayaran change order dapat mengcover seluruh biaya yang dikeluarkan oleh kontraktor akibat change order tersebut. 
Tabel 5. Mean Evaluasi Pengajuan Penerbitan Change Order

\begin{tabular}{|c|l|c|c|c|c|}
\hline \multirow{2}{*}{ No } & \multicolumn{1}{|c|}{ Pernyataan Kuesioner } & \multicolumn{2}{|c|}{$\begin{array}{c}\text { Mean } \\
\text { Frekuensi } \\
\text { Kejadian }\end{array}$} & $\begin{array}{c}\text { Mean } \\
\text { Tingkat } \\
\text { Kepentingan }\end{array}$ \\
\cline { 2 - 6 } & & Kon. & MK & Kon. & MK \\
\hline 4.1 & $\begin{array}{l}\text { Pembayaran change order dengan invoice terpisah dari invoice } \\
\text { tagihan termin }\end{array}$ & 4.11 & 4.50 & 4.05 & 4.39 \\
\hline 4.2 & $\begin{array}{l}\text { Pembayaran change order dilakukan secara langsung sesuai } \\
\text { dengan progress pekerjaan yang diselesaikan }\end{array}$ & 3.50 & 3.79 & 3.89 & 4.14 \\
\hline 4.3 & \begin{tabular}{l} 
Pembayaran change order dilakukan setelah proyek selesai \\
\hline
\end{tabular} & 3.45 & 3.86 & 3.09 & 3.50 \\
\hline
\end{tabular}

\subsection{Analisa Perbedaan Frekuensi Kejadian dan Tingkat Kepentingan Kontraktor dan MK}

Dapat dilihat pada Tabel 6. ada perbedaan frekuensi kejadian kontraktor dan MK dalam hal diterbitkannya site instruction oleh MK dengan nilai mean yaitu 3.84(Kon.) > 3.61(MK), dimana melalui uji T - Test terdapat perbedaan yang signifikan. Sehingga apabila MK sering menemui site instruction diterbitkan oleh MK, maka kontraktor jauh lebih sering lagi. Begitu pula untuk nilai tingkat kepentingannya yaitu 3.89(Kon.) > 3.57(MK), sehingga apabila MK merasa hal tersebut penting, maka kontraktor merasa site instruction oleh MK jauh lebih penting. Selain itu pula dapat dilihat pada Tabel 6 terdapat perbedaan frekuensi kejadian antara kontraktor dan MK mengenai change order yang telah dilaksanakan oleh kontraktor hanya dengan instruksi lisan dari owner tidak disetujui. Terlihat adanya perbedaan frekuensi kejadian antara kontraktor dan MK yaitu 3.77(Kon.) < 3.86(MK), melalui uji T - Test terdapat perbedaan yang signifikan. Sehingga apabila kontraktor sering menemui change order yang telah dilaksanakan oleh kontraktor hanya dengan instruksi lisan dari owner tidak disetujui, maka MK jauh lebih sering lagi Begitu juga untuk tingkat kepentingan antara kontraktor dan MK yaitu 3.48(Kon.) < 4.18(MK), dan telah dibuktikan melalui uji T - Test terdapat perbedaan yang signifikan. Sehingga apabila kontraktor merasa change order dengan instruksi lisan dari owner tidak disetujui merupakan hal yang penting, maka MK merasa hal tersebut jauh sangat penting.

Tabel 6. Perbedaan Frekuensi Kejadian dan Tingkat Kepentingan Kontraktor dan MK mengenai Prosedur Change Order

\begin{tabular}{|c|c|c|c|c|c|c|c|}
\hline \multirow{2}{*}{ No. } & \multirow{2}{*}{ Pernyataan } & \multirow{2}{*}{$\begin{array}{l}\text { Perbedaan } \\
\text { Frekuensi } \\
\text { Kejadian }\end{array}$} & \multicolumn{2}{|c|}{$\begin{array}{l}\text { Frekuensi } \\
\text { Kejadian }\end{array}$} & \multirow{2}{*}{$\begin{array}{l}\text { Perbedaan } \\
\text { Tingkat } \\
\text { Kepentingan }\end{array}$} & \multicolumn{2}{|c|}{$\begin{array}{c}\text { Tingkat } \\
\text { Kepentingan }\end{array}$} \\
\hline & & & Kon. & MK & & Kon. & MK \\
\hline 1.16 & Site instruction diterbitkan oleh MK. & Ada & 3.84 & 3.61 & Ada & 3.89 & 3.57 \\
\hline 3.3 & $\begin{array}{l}\text { Change order yang telah dilaksanakan } \\
\text { hanya dengan instruksi lisan dari owner } \\
\text { tidak disetujui. }\end{array}$ & Ada & 3.77 & 3.86 & Ada & 3.48 & 4.18 \\
\hline
\end{tabular}

\section{KESIMPULAN}

Tahapan identifikasi pengajuan penerbitan change order change order dapat diprakarsai oleh owner, kontraktor, dan MK. Dilihat pada proyek maka change order dengan site instruction dan tanpa site instruction masih terjadi pada proyek Kontraktor bersifat terikat dan harus mengerjakan change order apabila telah diberikan instruksi, kecuali apabila kontraktor 
tersebut tidak mampu mengerjakan change order dan dapat memberikan buktinya. kontraktor harus mengajukan proposal change order, yang terdiri dari gambar, spesifikasi material, permohonan biaya dan waktu serta bukti dokumentasi dalam bentuk foto kepada pihak owner atau perwakilannya. Tahapan evaluasi pengajuan penerbitan change order dilakukan setelah kontraktor mengajukan proposal terhadap owner, dan owner melaksanakan evaluasi atau pemeriksaan terhadap proposal tersebut. Aspek - aspek dalam prosedur yang terjadi adalah owner akan mengakui change order apabila pada proposal change order terdapat dokumen berupa perubahan gambar, perubahan spesifikasi dan merek material. Untuk pengukuran nilai dampak change order, pada tahap ini, owner atau perwakilannya akan mengevaluasi harga satuan yang digunakan yang harus menggunakan harga kontrak kecuali ada kondisi khusus. Tahapan approval penerbitan change order, dilakukannya negosiasi terlebih dahulu sebelum diberikan approval mengenai harga, sehingga kedua pihak memperoleh harga melalui negosiasi. Apabila negosiasi telah dilakukan dan kedua pihak setuju maka pihak owner atau perwakilannya yang diberikan wewenang akan memberikan tanda tangan pada proposal change order sebagai bukti approval. Apabila pada saat akan diberikan approval diketahui oleh owner atau perwakillannya bahwa change order tersebut tidak memiliki site instruction, maka minimal dapat digunakan bukti berupa minutes of meeting untuk memperkuat bukti change order tersebut. Tahapan akhir yaitu payment change order terdapat beberapa aspek yang perlu dilakukan yaitu, invoice change order secara terpisah dari invoice tagihan termin. Pembayaran yang dilakukan pada invoice haruslah sesuai dengan progress pekerjaan yang telah diselesaikan, sehingga tidak dibayarkan saat proyek selesai termasuk biaya langsung, dan waktu tambah yang diberikan kepada kontraktor diberikan dalam hari kalender.

\section{DAFTAR REFERENSI}

EINemr, W. (2001). Management of Change Order Claims in the Egyptian Industrial Construction Sector: Analysis and Means of Improvement. Unpublished Postgraduate Thesis, American University, Cairo.

Fisk, E. R. \& Reynolds, W. D. (2006). "Construction Project Administration(8 ${ }^{\text {th }}$ ed.)". New Jersey : Upper Saddle River : Prentice Hall International, Inc.

Gilbreath, R. D. (1992). "Managing Construction Contracts Operational Controls for Commercial Risks (2 ${ }^{\text {nd }}$ ed.)". John Wiley \& Sons, Inc. New York. Chicester. Brisbane. Toronto. Singapore.

Hardjomuljadi, S., Abdulkadir, A. \& Takei, M. (2006). "Strategi Klaim Konstruksi Berdasarkan FIDIC Conditions of Contract". Pola Grade. Jakarta.

Hardjomuljadi, S. (2008). "Persyaratan Kontrak untuk Pelaksanaan Konstruksi". Lembaga Pengembangan Jasa Konstruksi.

Hardjomuljadi, S. (2011). The Main Causal Factors of Construction Claims Under FIDIC Contract in Indonesia. Retrieved June 03, 2016, fromhttp://ssm.com/abstract=1898436.

Keane, P., Sertyesilisik, B. \& Ross, A.D. (2010). Variations and Change Orders on Construction Project. Journal of Legal Affairs and Dispute Resolution in Engineering and Construction, 2 (2), 89 - 96.

Swantari, P.I. (2013). Analisis Penyebab dan Dampak Change Order pada Bangunan Konstruksi di Bali. (NPM No.09 02 13325). Unpublished undergraduate thesis, Universitas Atma Jaya, Yogyakarta. 